\title{
The effect of seed addition and litter removal on plant composition in a coastal marsh of the Yellow River Delta
}

\author{
Liwen Zhang ${ }^{1,2}$ (D) Guangxuan $\operatorname{Han}^{1,2}$ \\ Received: 2 August 2020 / Revised: 24 November 2020 / Accepted: 25 December 2020 / Published online: 8 January 2021 \\ (C) The Author(s), under exclusive licence to Springer Nature B.V. part of Springer Nature 2021
}

\begin{abstract}
A obvious feature of many coastal wetlands is the relatively low plant species richness across different plant zones. The mechanisms of low plant species richness in the coastal wetland still need to be investigated. On the other hand, seed addition and litter removal are traditional measures to increase plant species richness in degraded ecosystems (such as grasslands and forests), but the effects of these interventions has not been greatly explored in coastal wetlands. We performed a seed addition and litter removal experiment in three coastal marsh vegetative zones characterized by Suaeda salsa, Aeluropus pungens, and Phragmites australis in the Yellow River Delta. The results showed that seed addition and litter removal treatments did not increase the species richness, plant density, or above-ground biomass over one growth season in each zone. We further found that the mechanisms limiting these measures was salinity in $S$. salsa and A. pungens zones, and water inundation in the $P$. australis zone, which may limit seed germination and seedling recruitment. Specifically, seed addition increased plant density of $P$. australis in the early growth season (May and June), but decreased it dramatically at the end of the growth season (September) due to water inundation. The interactive effect of seed addition and litter removal on average plant height varied by plant zone and growth season. Limitations in both seed germination and seedling recruitment may lead to lower species richness in coastal marsh plant zones and, more generally, it is unlikely that seed addition and litter removal will increase species richness in plant zones of degraded coastal wetlands with high environmental stress.
\end{abstract}

Keywords Seed addition $\cdot$ Litter removal $\cdot$ Coastal wetland $\cdot$ Yellow River Delta $\cdot$ Species richness $\cdot$ Species abundance

\section{Introduction}

In coastal wetlands, plant species often form distinct zones from the seaside (high salinity) to the upland (low salinity) along gradients of environmental stress. These zones typically have low species richness and are dominated by a single species. The patterns of plant species richness and species

Liwen Zhang

lwzhang@yic.ac.cn

Guangxuan Han

gxhan@yic.ac.cn

1 CAS Key Laboratory of Coastal Environmental Processes and Ecological Remediation, Yantai Institute of Coastal Zone Research (YIC), Chinese Academy of Sciences(CAS), Yantai 264003, People's Republic of China

2 Shandong Key Laboratory of Coastal Environmental Processes, YICCAS, Yantai, Shandong 264003, People's Republic of China distributions in these zones has been shown to be affected by seed limitation, seedling recruitment limitation, environmental factors, species interactions, and herbivory (Chen et al. 2020; Fenner 2000; Shumway and Bertness 1992; Vaccaro et al. 2009). Most coastal wetland studies have focused on the effects of environmental factors and species interactions while the effects of seed limitation and seedling recruitment limitation have rarely been investigated by experiments. Probing these mechanisms may help distinguish whether limited seed availability lead to the the local disappearance of species, leading to the low species richness observed in these areas today.

With the environmental change and human activities, the coastal wetland vegetation is deteriorating. The restoration of the vegetation of degraded coastal wetland become more and more important. From the ecological restoration perspective, aims of remediation include reestablishment of the dominant species and the enhancement of species richness of plant community where necessary (Torok and Helm 2017). The seed limitation hypothesis proposes that plant community richness and diversity are most limited by the regional species pool 
(Gough et al. 1994). Seed dispersal from neighboring communities may be able to compensate for the poor seed banks of the degraded community; however, limited seed dispersal, poor seed banks, and reduced microsites suitable for germination often restrain the establishment, development, and/or restoration of plant communities (Gough et al. 1994; Graham and Page 2018; Kiss et al. 2018; Zeiter and Stampfli 2008). Thus, adding seeds to the soil can augment the ecosystem recovery (Orth et al. 2012; Zamin et al. 2018) and promote the species diversity (Baattrup-Pedersen et al. 2013; Barr et al. 2017; Callister and Westbrooke 2017). It remains an open question whether seed addition can positively influence plant growth, plant density and species richness in degraded coastal wetlands, which exhibit high levels of abiotic stress.

Plant litter, including in situ standing dead plant tissues and scattered litters (debris), is prevalent in wetland plant communities at high latitudes due to slower decomposition rates. Litter decomposition plays an important role in nutrient cycling and soil fertility maintenance (Dias et al. 2017; Sayer 2006), which regulate the plant communities in coastal wetlands. Litter may help trap seeds dispersed by water or wind (Egawa and Tsuyuzaki 2013), influence the germination, recruitment, and establishment of seedlings through light interference (Dias et al. 2012; Holdredge and Bertness 2011; Sayer 2006) and the direction of intraspecific interactions of seedlings (Zhang and Wang 2016), and litters may also facilitate species invasion (Holdredge and Bertness 2011; Sarneel et al. 2014). Litter removal is a common measure tracked during ecological restoration (Klaus et al. 2017; Martin and Wilsey 2006), however, despite the large amounts of litter removed by tides in coastal wetlands (Minchinton 2002; Pennings and Richards 1998), the effects of litter removal on species establishment and richness in coastal wetlands has been little explored.

The interactive effect of seed addition and litter removal has varied between studies (e.g., Vaccaro et al. 2009; Klaus et al. 2017). Litter removal may create openings for seed germination, and thus increase plant density and species richness. However, standing vegetation and litters may lead to more heterogeneous microclimates by altering temperature and light environments(Török et al. 2020). It was reported that seed addition together with removal of grass swards increased species richness in agricultural grassland sites (Klaus et al. 2017). Some studies have found that litter had negative effect on plant survival and growth. For example, litter negatively influenced seedling survival and density in lake wetlands (Vaccaro et al. 2009). In coastal wetlands, litter removal may increase soil salinity in the summer and decrease the microclimate temperature in the winter-thereby inhibiting seed germination and seedling survival (Zhang and Wang 2016). This is in contrast with grassland findings, where litter removal facilitated seedling growth by increasing microclimate light levels (Camill et al. 2004).
Here we explored the effects of seed addition, litter remov$\mathrm{al}$, and their interaction on species composition in three coastal wetland zones to test the following hypotheses. (1) seed addition increases the number of seedlings and species richness in the litter retained treatment; (2) the positive effect of seed addition and litter retainment is stronger in plant zones with relatively high abiotic stress.

\section{Methods}

\section{Study site}

The study site was located in the Yellow River Delta, Shandong Province, east China $\left(38^{\circ} 05^{\prime} \mathrm{N}, 118^{\circ} 48^{\prime} \mathrm{E}\right)$, and has a warm-temperate regional climate (mean annual temperature and precipitation $12.1^{\circ} \mathrm{C}$ and $551.6 \mathrm{~mm}$, respectively). Precipitation mainly falls in the summer, and the average annual evaporation is about $1962 \mathrm{~mm}$. Tidal fluctuations in this region are irregularly semidiurnal. However, our study site was not inundated directly by the tide because a road inhibits its progress (Zhang and Wang 2019), and its underground water level was affected by sea tide. This type of coastal marsh is regionally ubiquitous because of seaside road construction. Salinity decreases from the seaside to the upland (Fig. S1a), and the plant zones are distinct; from the seaside to the upland: Suaeda salsa zone, Aeluropus pungens zone, and Phragmites australis zone. The most upland zone ( $P$. australis) is flooded from July to October by rainfall.

\section{Experiment design, plant and environmental factor monitoring, and data analysis}

We conducted two-factor randomized seed addition and litter removal experiments in each vegetative zone. Two levels were tested for both seed (control (NS) and seed addition (S)) and litter (control (L) and litter removal $(\mathrm{RL})$ ), for a total of four treatments. Each treatment had 3 replications, and thus 12 plots $(0.5 \times 0.5 \mathrm{~m})$ were established in each zone. In the "RL" treatment, all litter including litter layer and standing dead plant material was removed. In the "S" treatment, seeds of seven species native to coastal marshes in the Yellow River Delta were added (Fig. S2). These species included S. salsa, S. glauca, P. australis, Tripolium vulgare, Sonchus oleraceu, Cynanchum chinese, and Limonium sinense; the species $T$. vulgare, S. oleraceu, $C$. chinese, and $L$. sinense were rare in this marsh (Table S1). Seeds were collected from coastal wetlands of the Yellow River Delta from October to November of 2012 and air dried at the room temperature $\left(\sim 25{ }^{\circ} \mathrm{C}\right)$. We then vernalized the seeds by placing them in a nylon stocking filled with moist sand and storing them 
in darkness in a $0-4{ }^{\circ} \mathrm{C}$ refrigerator until early spring 2013. The seeds with the damp sand were sown evenly by hand broadcast in the seed addition plot on March 16, 2013. The seed addition treatment included 400 seeds of $S$. salsa, S. glauca and P. australis per plot, and 100 seeds of each other species due to limited seed availability. In the litter removal treatment, litter including in situ standing dead plant stems and scattered litter on the ground was carefully removed by hands and scissors, so that we did not disturb the soil.

We censused the species in May, June, and September, and measured the electronic conductivity in situ by the electronic conductivity meter (ECTestr 11, Spectrum Technologies, Inc., USA) and moisture by the HH2 moisture meter (delta-T devices Ltd., Cambridge, UK) in each plot. In June and September we measured and recorded the height of each individual in the plot. We counted all the plants in the plot including the mature vegetation and all the established sown plants. For the clonal plants such as the common reed, we regarded the number of stems as the individual numbers. The heights were not measured in May because the seedlings had just germinated. In September, we collected the above-ground biomass of each species in the plot and oven-dried for $72 \mathrm{~h}$ to obtain the total aboveground biomass of plots. To assess the effect of seed addition and litter removal on plant growth, the average species height and biomass of plant were calculated. In May, we measured the photosynthetically active radiation (PAR) using a Photosynthetic Active Radiometer (GLZ-A, TOP instrument, Zhejiang). Soil samples from $0-10$ to $10-20 \mathrm{~cm}$ were taken in each plot in September for soil physical and chemical properties $\left(\mathrm{pH}, \mathrm{TC}, \mathrm{NH}_{4}\right.$ $\mathrm{N}, \mathrm{NO}_{3}-\mathrm{N}, \mathrm{TN}, \mathrm{TP}$ and available $\mathrm{P}$ ) analysis. TC and TN were analyzed by Element Analyzer (Vario MACRO cube, Elmentar, Germany), $\mathrm{NH}_{4}-\mathrm{N}$ and $\mathrm{NO}_{3^{-}}$ $\mathrm{N}$ were measured by Continuous Flowing Analyzer (AutoAnalyzer III, Seal, Germany), and TP and Available $\mathrm{P}$ were analyzed by the Mo-Sb Colorimetric Method.Normal distribution of residuals and the homogeneity of variance were tested by the Shapiro-Wilk normality test and the Levene's test. When residuals were normally distributed and variances homogeneous, two-way ANOVA was used for hypothesis testing; otherwise, the Scheirer-Ray-Hare test was used. The Tukey HSD test and Dunn's Kruskal-Wallis multiple comparisons test were used to compare the means of significant treatment levels. The linear regression was employed to analyze the effect of environmental factors on the plant biomass, species richness and plant density of the plots. The best model was chosen by AIC (Akaike Information Criterion) in a stepwise algorithm. All data analyses were conducted in the $\mathrm{R}$ i386 3.5.2 software.

\section{Results}

\section{The effects of seed addition and litter removal on plant density}

No significant effect of seed addition or litter removal was detected on plant density in $S$. salsa and A. pungens zones regardless of plant growth periods (Fig. 1; Tables 1, S2). In the $P$. australis zone, seed addition had a significantly positive effect on plant density in May and June (the seedling period; May: $\mathrm{F}=0.202 \times 10^{3}, P<0.001$; June: $\mathrm{F}=8.301, P=0.020$ ); however, there was no significant effect on plant density by the end of the growing season in September (Fig. 1; Tables 1, S2). In May in the $P$. australis zone, plant density reached 617 \pm 59 individuals per plot in the seed addition treatment, while the control had a plant density of only $77 \pm 8$ individuals per plot. In June, the plant density of seed addition plot was 579 \pm 138 individuals per plot - much higher than that of the control (170 \pm 20 individuals per plot) (Table 2).

\section{The effects of seed addition and litter removal on plant growth and species richness}

The effects of seed and litter treatments on average plant height had strong seasonal and plant zone variation (Fig. 2; Tables 3-4, S3). In the $S$. salsa zone, we found significant interactions between seed and litter treatment on mean plant height in June $(P<0.001)$ and September $(P=0.011)$; the NSL (Litter retained without seed addition) and SRL (Litter removal and seed addition) treatment had similar mean plant heights, and the NSRL (Litter removal without seed adition) and SL (Litter retained and seed addition) treatment had similar mean plant height (Tables 4, S3; NSL: $10.07 \pm 0.30 \mathrm{~cm}$; NSRL: 8.29 $\pm 0.21 \mathrm{~cm}$; SL: $7.78 \pm 0.27 \mathrm{~cm}$; SRL: $9.21 \pm 0.24 \mathrm{~cm})$. In September, litter removal alone also significantly reduced average plant height $(P<0.001$; L: $47.47 \pm 0.59 \mathrm{~cm}$; RL: 50.47 $\pm 0.58 \mathrm{~cm}$; Table S3).

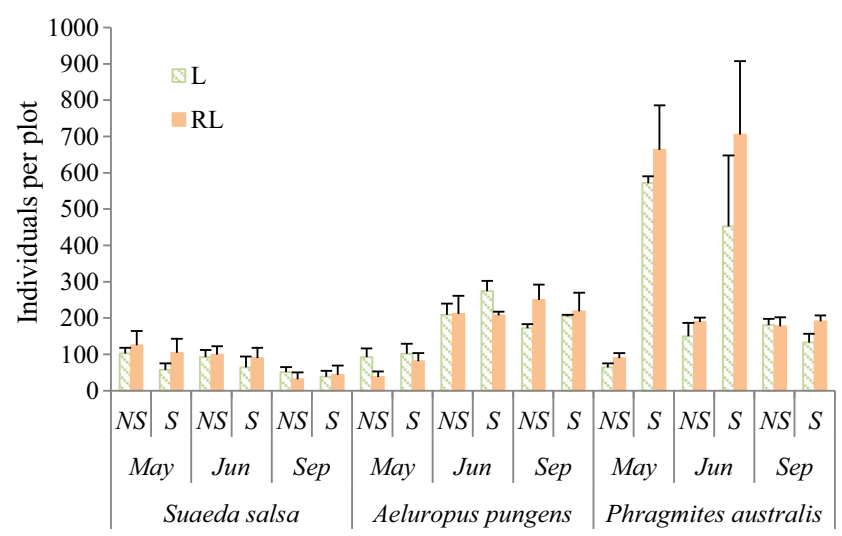

Fig. 1 Mean plot community abundances. "NS"; no seed addition; "S", seed addition; "L", litter retained; and "RL", litter removal. Whiskers denote standard error 
Table 1 Two-way ANOVA of the effects of seed addition and litter removal treatments on the numbers of plant individuals. The data of Phragmites australis in May was log-transformed

\begin{tabular}{|c|c|c|c|c|c|c|c|}
\hline $\begin{array}{l}\text { Vegetative } \\
\text { zone }\end{array}$ & Month & $\begin{array}{l}\text { Source of } \\
\text { variation }\end{array}$ & Df & $\begin{array}{l}\text { Sum of } \\
\text { squares }\end{array}$ & $\begin{array}{l}\text { Mean } \\
\text { square }\end{array}$ & F value & $P$ value \\
\hline \multirow[t]{12}{*}{ Suaeda salsa } & \multirow[t]{4}{*}{ May } & Seed & 1 & $3.234 \times 10^{3}$ & $3.234 \times 10^{3}$ & 1.212 & 0.303 \\
\hline & & Litter & 1 & $3.640 \times 10^{3}$ & $3.640 \times 10^{3}$ & 1.365 & 0.276 \\
\hline & & Seed: litter & 1 & $0.444 \times 10^{3}$ & $0.444 \times 10^{3}$ & 0.167 & 0.694 \\
\hline & & Residuals & 8 & $2.134 \times 10^{4}$ & $2.667 \times 10^{3}$ & & \\
\hline & \multirow[t]{4}{*}{ June } & Seed & 1 & $1.121 \times 10^{3}$ & $1.121 \times 10^{3}$ & 0.514 & 0.494 \\
\hline & & Litter & 1 & $0.800 \times 10^{3}$ & $0.800 \times 10^{3}$ & 0.367 & 0.561 \\
\hline & & Seed: litter & 1 & $0.280 \times 10^{3}$ & $0.280 \times 10^{3}$ & 0.129 & 0.729 \\
\hline & & Residuals & 8 & $1.744 \times 10^{4}$ & $2.180 \times 10^{3}$ & & \\
\hline & \multirow[t]{4}{*}{ September } & Seed & 1 & $0.801 \times 10^{2}$ & $0.801 \times 10^{2}$ & 0.076 & 0.790 \\
\hline & & Litter & 1 & $0.690 \times 10^{3}$ & $0.690 \times 10^{3}$ & 0.653 & 0.442 \\
\hline & & Seed: litter & 1 & $0.169 \times 10^{3}$ & $0.169 \times 10^{3}$ & 0.160 & 0.700 \\
\hline & & Residuals & 8 & $8.450 \times 10^{3}$ & $1.056 \times 10^{3}$ & & \\
\hline \multirow{12}{*}{$\begin{array}{l}\text { Aeluropus } \\
\text { pungens }\end{array}$} & \multirow[t]{4}{*}{ May } & Seed & 1 & $2.106 \times 10^{3}$ & $2.106 \times 10^{3}$ & 1.377 & 0.274 \\
\hline & & Litter & 1 & $4.218 \times 10^{3}$ & $4.218 \times 10^{3}$ & 2.757 & 0.135 \\
\hline & & Seed: litter & 1 & $0.850 \times 10^{3}$ & $0.850 \times 10^{3}$ & 0.556 & 0.477 \\
\hline & & Residuals & 8 & $1.224 \times 10^{4}$ & $1.530 \times 10^{3}$ & & \\
\hline & \multirow[t]{4}{*}{ June } & Seed & 1 & $2.760 \times 10^{3}$ & $2.760 \times 10^{3}$ & 0.852 & 0.383 \\
\hline & & Litter & 1 & $3.072 \times 10^{3}$ & $3.072 \times 10^{3}$ & 0.948 & 0.359 \\
\hline & & Seed: litter & 1 & $3.536 \times 10^{3}$ & $3.536 \times 10^{3}$ & 1.092 & 0.327 \\
\hline & & Residuals & 8 & $2.592 \times 10^{4}$ & $3.239 \times 10^{3}$ & & \\
\hline & \multirow[t]{4}{*}{ September } & Seed & 1 & 1.3 & 1.3 & $0.4 \times 10^{-3}$ & 0.985 \\
\hline & & Litter & 1 & $6.256 \times 10^{3}$ & $6.256 \times 10^{3}$ & 1.842 & 0.212 \\
\hline & & Seed: litter & 1 & $3.072 \times 10^{3}$ & $3.072 \times 10^{3}$ & 0.905 & 0.369 \\
\hline & & Residuals & 8 & $2.717 \times 10^{4}$ & $3.396 \times 10^{3}$ & & \\
\hline \multirow{12}{*}{$\begin{array}{c}\text { Phragmites } \\
\text { australis }\end{array}$} & \multirow[t]{4}{*}{ May } & Seed & 1 & 13.311 & 13.311 & $0.202 \times 10^{3}$ & $<0.001^{* * * *}$ \\
\hline & & Litter & 1 & 0.155 & 0.155 & 2.360 & 0.163 \\
\hline & & Seed: litter & 1 & 0.036 & 0.036 & 0.540 & 0.483 \\
\hline & & Residuals & 8 & 0.527 & 0.066 & & \\
\hline & \multirow[t]{4}{*}{ June } & Seed & 1 & $5.023 \times 10^{5}$ & $5.023 \times 10^{5}$ & 8.301 & $0.020^{*}$ \\
\hline & & Litter & 1 & $6.409 \times 10^{4}$ & $6.409 \times 10^{4}$ & 1.059 & 0.333 \\
\hline & & Seed: litter & 1 & $3.403 \times 10^{4}$ & $3.403 \times 10^{4}$ & 0.562 & 0.475 \\
\hline & & Residuals & 8 & $4.480 \times 10^{5}$ & $6.051 \times 10^{4}$ & & \\
\hline & \multirow[t]{4}{*}{ September } & Seed & 1 & $0.850 \times 10^{3}$ & $0.850 \times 10^{3}$ & 0.656 & 0.441 \\
\hline & & Litter & 1 & $2.269 \times 10^{3}$ & $2.268 \times 10^{3}$ & 1.751 & 0.222 \\
\hline & & Seed: litter & 1 & $2.791 \times 10^{3}$ & $2.791 \times 10^{3}$ & 2.154 & 0.180 \\
\hline & & Residuals & 8 & $1.036 \times 10^{4}$ & $1.295 \times 10^{3}$ & & \\
\hline
\end{tabular}

In June in the $A$. pungens zone, seed addition $(P<0.001$; NS: $25.21 \pm 0.29 \mathrm{~cm}$; S: $27.50 \pm 0.30 \mathrm{~cm})$, litter removal $(\mathrm{P}<0.001 ; \mathrm{L}: 27.94 \pm 0.31 \mathrm{~cm}$; $\mathrm{RL}: 24.69$ $\pm 0.27 \mathrm{~cm})$, and their interaction $(P<0.0011$; NSL: $23.48 \pm 0.47 \mathrm{~cm}$; NSRL: $26.92 \pm 0.32 \mathrm{~cm}$; SL: 31.35 $\pm 0.37 \mathrm{~cm}$; SRL: $22.42 \pm 0.42 \mathrm{~cm})$ had significant effects on the plant height in June (Tables 4, S3). At the end of the growing season, in September in A. pungens zone, both litter treatment $(\mathrm{P}<0.001 ; \mathrm{L}$ : 31.51 $\pm 0.44 \mathrm{~cm}$; RL: $24.11 \pm 0.23 \mathrm{~cm})$ and the interaction between seed and litter treatment $(\mathrm{P}<0.001$; NSL: 28.85 


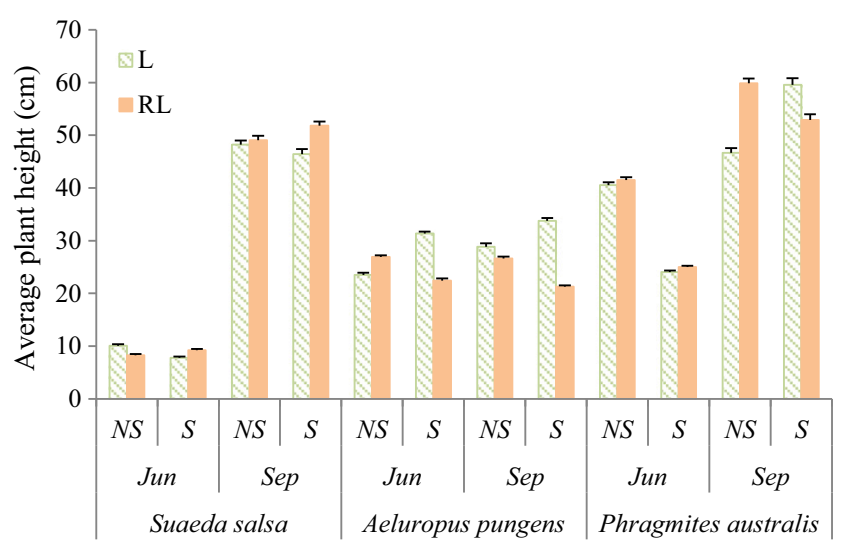

Fig. 2 Mean plot plant height. "NS"; no seed addition; "S", seed addition; "L", litter retained; and "RL", litter removal. Whiskers denote standard error

$\pm 0.67 \mathrm{~cm}$; NSRL: $26.64 \pm 0.36 \mathrm{~cm}$; SL: $33.75 \pm 0.57 \mathrm{~cm}$; SRL: $21.27 \pm 0.24 \mathrm{~cm}$ ) significantly influenced mean plant height.

In the most upland zone ( $P$. australis) in June, seed $(\mathrm{P}<0.001$; NS: $41.09 \pm 0.39 \mathrm{~cm}$; S: $24.63 \pm 0.18 \mathrm{~cm})$ and litter treatment $(P=0.002 ; \mathrm{L}: 28.17 \pm 0.30 \mathrm{~cm} ; \mathrm{RL}: 28.49 \pm 0.26 \mathrm{~cm})$ independently affected mean plant height. In September, litter treatment $(\mathrm{P}<0.001 ; \mathrm{L}: 52.14 \pm 0.79 \mathrm{~cm} ; \mathrm{RL}: 56.28 \pm 0.71 \mathrm{~cm})$ and the interaction of seed and litter treatment $(\mathrm{P}<0.001$;
NSL: $46.67 \pm 0.92 \mathrm{~cm}$; NSRL: $59.89 \pm 0.89 \mathrm{~cm}$; SL: 59.57 $\pm 1.28 \mathrm{~cm}$; SRL: $52.93 \pm 1.07 \mathrm{~cm}$ ) had significant effects on the average community height growth (Appendices Table S3).

However, seed addition and litter removal treatment had no significant effects on above-ground biomass at the end of the growing season in any of the three plant zones (Fig. 3, Table 5).

We found little evidence that the seed addition and litter removal treatment increased species richness (Fig. 4; Table 6). However, seed addition would have a marginally significant effect on the species richness in September of $P$. australis zone $(P=0.058)$.

\section{Environment factors}

The three plant zones had different soil physical and chemical properties (Fig. S1). The P. australis zone had the lowest salinity in May, June, and September (Fig. S1a), the highest moisture in September, but lowest moisture in June (Fig. S1b). The $\mathrm{pH}$ of $S$. salsa zone was lower than that of the A. pungens and $P$. australis zones (Fig. S1c). The $\mathrm{NH}_{4}-\mathrm{N}$ content in the A. pungens zone was higher than in the other zones (Fig. S1d), but $\mathrm{NO}_{3}-\mathrm{N}$ content and Available N was highest in the $S$. salsa
Table 3 Two-way ANOVA of the effects of seed addition and litter removal treatments on plant height

\begin{tabular}{|c|c|c|c|c|c|c|}
\hline $\begin{array}{l}\text { Vegetative } \\
\text { zone }\end{array}$ & Month & $\begin{array}{l}\text { Source of } \\
\text { variation }\end{array}$ & Df & $\begin{array}{l}\text { Sum of } \\
\text { squares }\end{array}$ & $\begin{array}{l}\mathrm{H} \text { value or } \mathrm{F} \\
\text { value }\end{array}$ & $P$ value \\
\hline \multirow[t]{8}{*}{ S. salsa } & \multirow[t]{4}{*}{ June } & Seed & 1 & $3.361 \times 10^{5}$ & 3.758 & 0.053 \\
\hline & & Litter & 1 & $4.252 \times 10^{4}$ & 0.475 & 0.491 \\
\hline & & Seed: litter & 1 & $3.731 \times 10^{6}$ & 41.716 & $<0.001^{* * * *}$ \\
\hline & & Residuals & 1032 & $8.847 \times 10^{7}$ & & \\
\hline & \multirow[t]{4}{*}{ September } & Seed & 1 & $5.156 \times 10^{4}$ & 1.553 & 0.213 \\
\hline & & Litter & 1 & $6.635 \times 10^{5}$ & 19.989 & $<0.001^{\text {**** }}$ \\
\hline & & Seed: litter & 1 & $2.150 \times 10^{5}$ & 6.478 & $0.011^{*}$ \\
\hline & & Residuals & 627 & $1.998 \times 10^{7}$ & & \\
\hline \multirow[t]{8}{*}{ A. pungens } & \multirow[t]{4}{*}{ June } & Seed & 1 & $2.587 \times 10^{7}$ & 42.483 & $<0.001^{\text {*** }}$ \\
\hline & & Litter & 1 & $5.844 \times 10^{7}$ & 95.959 & $<0.001^{\text {*** }}$ \\
\hline & & Seed: litter & 1 & $1.239 \times 10^{8}$ & $0.203 \times 10^{3}$ & $<0.001^{\text {*** }}$ \\
\hline & & Residuals & 2700 & $1.438 \times 10^{9}$ & & \\
\hline & \multirow[t]{4}{*}{ September } & Seed & 1 & $6.094 \times 10^{5}$ & 1.140 & 0.287 \\
\hline & & Litter & 1 & $9.218 \times 10^{7}$ & $0.172 \times 10^{3}$ & $<0.001^{\text {**** }}$ \\
\hline & & Seed: litter & 1 & $7.524 \times 10^{7}$ & $0.140 \times 10^{3}$ & $<0.001^{* * * *}$ \\
\hline & & Residuals & 2530 & $1.186 \times 10^{9}$ & & \\
\hline \multirow[t]{8}{*}{ P. australis } & \multirow[t]{4}{*}{ June } & Seed & 1 & $1.797 \times 10^{9}$ & $1.205 \times 10^{3}$ & $<0.001^{* * * *}$ \\
\hline & & Litter & 1 & $1.416 \times 10^{7}$ & 9.50 & $0.002^{* * * *}$ \\
\hline & & Seed: litter & 1 & $1.152 \times 10^{5}$ & 0.08 & 0.781 \\
\hline & & Residuals & 4485 & $4.880 \times 10^{9}$ & & \\
\hline & \multirow[t]{4}{*}{ September } & Seed & 1 & $3.467 \times 10^{5}$ & 0.995 & 0.319 \\
\hline & & Litter & 1 & $6.516 \times 10^{6}$ & 18.696 & $<0.001^{\text {**** }}$ \\
\hline & & Seed: litter & 1 & $4.087 \times 10^{7}$ & $0.117 \times 10^{3}$ & $<0.001^{* * * *}$ \\
\hline & & Residuals & 2041 & $6.647 \times 10^{8}$ & & \\
\hline
\end{tabular}


Table 4 Multiple comparisons of mean $( \pm \mathrm{SE})$ plant height of different interactive treatment levels. "NSL", "NSRL", "SL" and "SRL" are the interactive terms of the seed addition and litter removal. "NSL", litter retained without seed addition; "NSRL", litter removal without seed addition; "SL", litter retained and seed addition; and "SRL", litter removal and seed addition

\begin{tabular}{|c|c|c|c|c|c|}
\hline \multirow[t]{2}{*}{ Vegetative zone } & \multirow[t]{2}{*}{ Month } & \multicolumn{4}{|l|}{ Treatments } \\
\hline & & NSL (cm) & $\operatorname{NSRL}(\mathrm{cm})$ & $\mathrm{SL}(\mathrm{cm})$ & $\mathrm{SRL}(\mathrm{cm})$ \\
\hline \multirow[t]{2}{*}{ S. salsa } & June & $10.07 \pm 0.30 \mathrm{a}$ & $8.29 \pm 0.21 \mathrm{~b}$ & $7.78 \pm 0.27 \mathrm{~b}$ & $9.21 \pm 0.24 \mathrm{a}$ \\
\hline & September & $48.25 \pm 0.73 \mathrm{ab}$ & $49.08 \pm 0.85 \mathrm{a}$ & $46.43 \pm 0.95 \mathrm{~b}$ & $51.83 \pm 0.78 \mathrm{c}$ \\
\hline \multirow[t]{2}{*}{ A. pungens } & June & $23.48 \pm 0.47 \mathrm{a}$ & $26.92 \pm 0.32 \mathrm{~b}$ & $31.35 \pm 0.37 \mathrm{~b}$ & $22.42 \pm 0.42 \mathrm{~d}$ \\
\hline & September & $28.85 \pm 0.67 \mathrm{a}$ & $26.64 \pm 0.36 \mathrm{a}$ & $33.75 \pm 0.57 \mathrm{~b}$ & $21.27 \pm 0.24 \mathrm{c}$ \\
\hline \multirow[t]{2}{*}{ P. australis } & June & $40.55 \pm 0.56 \mathrm{a}$ & $41.51 \pm 0.53 \mathrm{a}$ & $24.07 \pm 0.27 \mathrm{~b}$ & $24.99 \pm 0.24 \mathrm{c}$ \\
\hline & September & $46.67 \pm 0.92 \mathrm{a}$ & $59.89 \pm 0.89 \mathrm{~b}$ & $59.57 \pm 1.28 \mathrm{~b}$ & $52.93 \pm 1.07 \mathrm{c}$ \\
\hline
\end{tabular}

zone (Fig. S1e-f). The TC was significantly different between the three zones, and highest in the $P$. australis zone (Fig. S1g). $\mathrm{TN}$ in the $P$. australis zone was higher than in the $S$. salsa zone, but not different from the A. pungens zone (Fig. S1h). There were no significant differences in TP or Available P between soils in these zones (Fig. S1i-j). The effect of litter removal on PAR was significantly higher than the litter retained treatment (Fig. S3).

The total above-ground biomass were significantly influenced by the soil moisture in May and June, PAR, TP of soil $0-10 \mathrm{~cm}$, TC of soil $0-10 \mathrm{~cm}$ and TN of soil $0-10 \mathrm{~cm}$ (Table S4 a). Species richness were significantly affected by EC in Sept., Available P of soil $10-20 \mathrm{~cm}, \mathrm{NH}_{4}-\mathrm{N}$ of soil 0 $10 \mathrm{~cm}$ and $\mathrm{NO}_{3}-\mathrm{N}$ content of soil $0-10 \mathrm{~cm}$, Available $\mathrm{N}$ of soil $0-10 \mathrm{~cm}$, TC of soil $0-20 \mathrm{~cm}$ and TN of soil $0-20 \mathrm{~cm}$ (Table S4 b). The plant density of the plots were significantly influenced by PAR, Available P of soil 0-10 cm, TC of soil 0$20 \mathrm{~cm}$ and TN of soil 0-20 cm (Table S4 c).

\section{Discussion}

\section{Seed addition}

We found that coastal marsh plant species richness and aboveground biomass did not increase, and the community

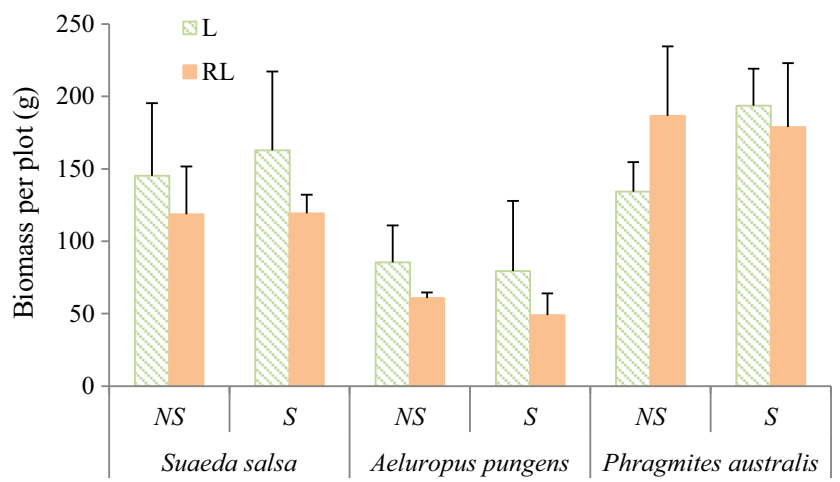

Fig. 3 Mean plot September above-ground biomass. "NS"; no seed addition; "S", seed addition; "L", litter retained; and "RL", litter removal. Whiskers denote standard error composition did not change, despite the addition of thousands of seeds from multiple species plant in three plant zones after one growing season. Positive effects of seed addition on plant density were observed in May and June-during germination and early growth periods - in the $P$. australis zone. Seed addition also positively influenced average plant height in June in the A. pungens and P. australis zones. However, positive effects of seed addition on mean plant density and height were no longer detected by the end of the season. This suggests that not seed limitation but establishment limitation is the driving force in the studied wetlands.

These findings contrast with studies in grasslands (Callister and Westbrooke 2017; Hoelzle et al. 2012; Johnson et al. 2018; Martin and Wilsey 2006; Zamin et al. 2018). For instance, seed addition increased the seedling emergence of rare species in a prairie grassland (Martin and Wilsey 2006), and in another grassland, seed addition from ten species introduced six new forbs that persisted for 3 years (Zamin et al. 2018). Studies in temperate grasslands have also shown that seed addition can increase species richness and abundance of sown native forbs (Johnson et al. 2018). However, in the coastal wetland, seed germination may be negatively influenced by environmental stress. The influential environmental factor in our study was salinity stress, which had been demonstrated to limit seedling recruitment, except in salt-tolerant species (Shumway and Bertness 1992). In our experiments, seed addition only increased species richness of seedlings in $P$. australis zone. This may be because salinity stress was higher in S. salsa and A. pungens zones. S. salsa and $P$. australis have different stress tolerances, and $S$. salsa has very high salt tolerance (Kefu et al. 2003; Zhang et al. 2017). $S$. salsa can germinate in all three plant zones, but $P$. australis cannot germinate in the $S$. salsa and A. pungens zones due to high salinity. However, $S$. salsa abundance in the $P$. australis zone is dramatically reduced annually in the later growth season when high water levels (beginning in July) cause longperiod inundation that prevents recruitment to the adult stage. Therefore, $P$. australis invasion into the $S$. salsa zone is limited by salinity, while $S$. salsa invasion of the $P$. australis zone is limited by water inundation. In the field, with the exceptions of $S$. salsa and P. australis, species had strong seed dispersal 
Table 5 Two-way ANOVA of the effects of seed addition and litter removal treatments on September biomass

\begin{tabular}{lllllll}
\hline Vegetative zone & Source of variation & Df & Sum of squares & Mean square & F value & P value \\
\hline S. salsa & Seed & 1 & $0.249 \times 10^{3}$ & $0.249 \times 10^{3}$ & 0.148 & 0.711 \\
& Litter & 1 & $3.667 \times 10^{3}$ & $3.667 \times 10^{3}$ & 2.178 & 0.178 \\
& Seed: litter & 1 & $0.217 \times 10^{3}$ & $0.217 \times 10^{3}$ & 0.129 & 0.729 \\
& Residuals & 8 & $1.347 \times 10^{4}$ & $1.684 \times 10^{3}$ & & \\
A. pungens & Seed & 1 & $0.243 \times 10^{3}$ & $0.243 \times 10^{3}$ & 0.301 & 0.598 \\
& Litter & 1 & $2.281 \times 10^{3}$ & $2.281 \times 10^{3}$ & 2.824 & 0.131 \\
& Seed: litter & 1 & 23.500 & 23.490 & 0.029 & 0.869 \\
& Residuals australis & 8 & $6.462 \times 10^{3}$ & $0.808 \times 10^{3}$ & & \\
& Seed & 1 & $2.022 \times 10^{3}$ & $2.022 \times 10^{3}$ & 1.523 & 0.252 \\
& Litter & 1 & $1.054 \times 10^{3}$ & $1.054 \times 10^{3}$ & 0.794 & 0.399 \\
& Seed: litter & 1 & $3.377 \times 10^{3}$ & $3.377 \times 10^{3}$ & 2.543 & 0.149
\end{tabular}

limitations and unavailable in the seed bank (unpublished data). These combined limitations in dispersal, seed germination, and seedling recruitment likely underlie the low species richness of coastal marsh plant zones.

\section{Litter removal, and its interaction with seed addition}

Litter removal alone (main effect) had no effect on plant density, richness, or above-ground biomass, but it had varying effects on plant height in different zones and seasons. Litter removal in the $S$. salsa and A. pungens zones lead to significantly reduced average plant height in September. In contrast, in the $P$. australis zone, litter removal alone significantly increased average plant height in June and September. Litter removal may enhance the vertical growth of $P$. australis because it increases the PAR at ground level. In the higher elevation $S$. salsa and A. pungens zones where salinity is already high, litter removal may increase salinity stress (Zhang and Wang 2016). Similar results were observed by Xiong et al. (2003): litter addition had a negative effect on seedling

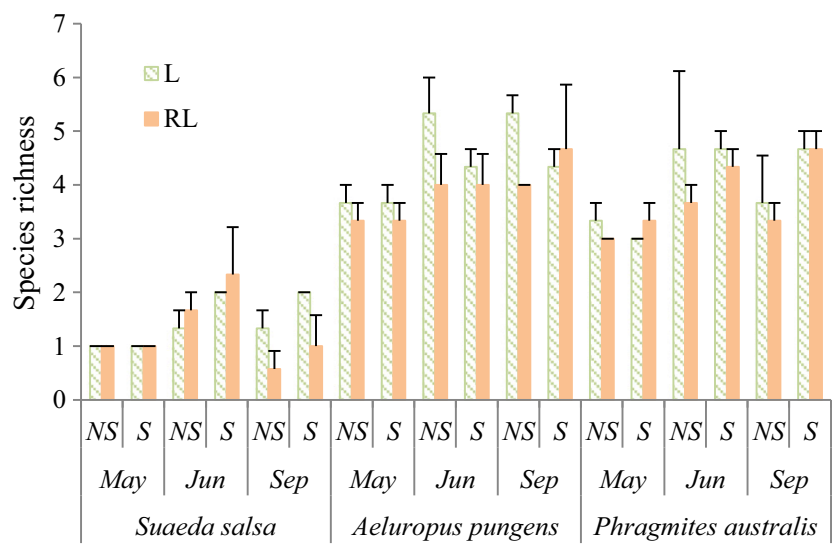

Fig. 4 Mean plot species richness. "NS"; no seed addition; "S", seed addition; "L", litter retained; and "RL", litter removal. Whiskers denote standard error emergence at low elevations, but positive effects at the high elevation.

The interaction of seed addition and litter removal also had no effects on species richness, plant density, or above-ground biomass. This also contrasts with previous observations. Litter was reported to positively affect the number of seeds in the seed bank by trapping seeds and thereby enhancing species richness (Egawa and Tsuyuzaki 2013). Dias et al. (2012) found that seed and litter addition resulted in greater seedling abundance than either added seed or litter additional alone. On the other hand, we found soil moisture, EC, PAR and soil nutrients strongly influenced the biomass, species richness and plant density in this coastal marsh. These environmental factors also varied among plant zones which may contribute to structuring the community composition of the plant zones. Thus, in coastal marshes, retained litter may not change these environmental factors which were often vital to newly germinated seeds, seedlings and plant growth.

Similar to the effects of litter alone, the interactive effects of seed addition and litter removal on average plant height depended on plant zones and season. In the S. salsa and A. Pungent zones, the interaction of seed and litter significantly affected average plant height in June and September, but in the $P$. australis zone, the interaction significantly affected plant height only in September. However, the combination of treatments and their resulting effects were different in each case. Seed addition with litter removal increased average height in $S$. salsa zones but seed addition and litter retention increased average plant height in A. pungens zones. Finally, seed non-addition and litter removal increased the average plant height in $P$. australis zones. These findings highlight the heterogeneity between plant zones even within a single coastal marsh region. In summary, seed addition and litter removal did not affect species richness, plant density, or above-ground biomass in a single growing season in three plant zones of a coastal marsh of the Yellow River Delta. It 
Table 6 Two-way ANOVA of the effect of seed addition and litter removal treatments on species richness

\begin{tabular}{lllllll}
\hline Vegetative zone & Source of variation & Df & Sum of squares & Mean square & F value & P value \\
\hline S. salsa & Seed & 1 & 0.750 & 0.750 & 1.800 & 0.217 \\
& Litter & 1 & 0.083 & 0.083 & 0.200 & 0.667 \\
& Seed: litter & 1 & 0.083 & 0.083 & 0.200 & 0.667 \\
A. pungens & Residuals & 8 & 3.333 & 0.417 & & \\
& Seed & 1 & 0.083 & 0.083 & 0.067 & 0.803 \\
& Litter & 1 & 0.750 & 0.750 & 0.600 & 0.461 \\
& Seed: litter & 1 & 2.083 & 2.083 & 1.667 & 0.233 \\
P. australis & Residuals & 8 & 10.000 & 1.250 & & \\
& Seed & 1 & 4.083 & 4.083 & 4.900 & 0.058 \\
& Litter & 1 & 0.083 & 0.083 & 0.100 & 0.760 \\
& Seed: litter & 1 & 0.083 & 0.083 & 0.100 & 0.760
\end{tabular}

is likely that environmental factors such as salinity and water inundation may limit seed germination and seedling recruitment to a great degree. Seed addition did increase plant density of the $P$. australis zone in the early growth season (May and June), but water inundation at the end of the growing season dramatically decreased density by the end of the experiment. Therefore, the biomass, plant density and species richness in the plant zones of the coastal marsh may be attributed to the abiotic factors such as salinity, moisture and soil nutrients. Our findings also suggest that seed addition and litter removal may not be fruitful restoration methods in degraded coastal marsh plant zones.

Supplementary Information The online version contains supplementary material available at https://doi.org/10.1007/s11852-020-00795-z.

Acknowledgements This research was funded by National Natural Science Foundation of China (No. 31100313) and the Youth Innovation Promotion Association CAS (2018247). We would like to thank Dr. Ian Gilman at Yale University for his assistance with English language and grammatical editing.

\section{References}

Baattrup-Pedersen A, Dalkvist D, Dybkjaer JB, Riis T, Larsen SE, Kronvang B (2013) Species recruitment following flooding, sediment deposition and seed addition in restored riparian areas. Restor Ecol 21:399-408

Barr S, Jonas JL, Paschke MW (2017) Optimizing seed mixture diversity and seeding rates for grassland restoration. Restor Ecol 25:396-404

Callister K, Westbrooke M (2017) A field trial to test effects of watering, seed addition and disturbance on perennial species recruitment in Belah woodland. Ecol Manag Restor 18:246-249

Camill P, McKone MJ, Sturges ST, Severud WJ, Ellis E, Limmer J, Martin CB, Navratil RT, Purdie AJ, Sandel BS, Talukder S, Trout A (2004) Community- and ecosystem-level changes in a speciesrich tallgrass prairie restoration. Ecol Appl 14:1680-1694
Chen L, Zhang LW, Liu ZT, Lu F, Feng GH, Yan K and Han GX (2020) Physiological and ecological responses of hetan and chaotan Phragmites australis to salt stress. Acta Ecologica Sinca 40: 2090-2098

Dias ATC, Bozelli RL, Darigo RM, Esteves FD, dos Santos HF, Figueiredo-Barros MP, Nunes MFQS, Roland F, Zamith LR, Scarano FR (2012) Rehabilitation of a bauxite tailing substrate in Central Amazonia: the effect of litter and seed addition on floodprone forest restoration. Restor Ecol 20:483-489

Dias ATC, Cornelissen JHC, Berg MP (2017) Litter for life: assessing the multifunctional legacy of plant traits. J Ecol 105:1163-1168

Egawa C, Tsuyuzaki S (2013) The effects of litter accumulation through succession on seed bank formation for small- and large-seeded species. J Veg Sci 24:1062-1073

Fenner M (2000) Seeds: the ecology of regeneration in plant communities. CABI Pub., Oxon

Gough L, Grace JB, Taylor KL (1994) The relationship between species richness and community biomass - the importance of environmental variables. Oikos 70:271-279

Graham LLB and Page SE (2018) A limited seed bank in both natural and degraded tropical peat swamp forest: the implications for restoration. Mires and Peat 22: 1-12

Hoelzle TB, Jonas JL, Paschke MW (2012) Twenty-five years of sagebrush steppe plant community development following seed addition. J Appl Ecol 49:911-918

Holdredge C, Bertness MD (2011) Litter legacy increases the competitive advantage of invasive Phragmites australis in New England wetlands. Biol Invasions 13:423-433

Johnson DP, Catford JA, Driscoll DA, Gibbons P (2018) Seed addition and biomass removal key to restoring native forbs in degraded temperate grassland. Appl Veg Sci 21:219-228

Kefu Z, Hai F, San Z, Jie S (2003) Study on the salt and drought tolerance of Suaeda salsa and Kalanchoe claigremontiana under iso-osmotic salt and water stress. Plant Sci 165:837-844

Kiss R, Deak B, Torok P, Tothmeresz B, Valko O (2018) Grassland seed bank and community resilience in a changing climate. Restor Ecol 26:S141-S150

Klaus VH, Schafer D, Kleinebecker T, Fischer M, Prati D, Holzel N (2017) Enriching plant diversity in grasslands by large-scale experimental sward disturbance and seed addition along gradients of landuse intensity. J Plant Ecol 10:581-591

Martin LM, Wilsey BJ (2006) Assessing grassland restoration success: relative roles of seed additions and native ungulate activities. J Appl Ecol 43:1098-1109 
Minchinton TE (2002) Disturbance by wrack facilitates spread of Phragmites australis in a coastal marsh. J Exp Mar Biol Ecol 281: 89-107

Orth RJ, Moore KA, Marion SR, Wilcox DJ, Parrish DB (2012) Seed addition facilitates eelgrass recovery in a coastal bay system. Mar Ecol Prog Ser 448:177-195

Pennings SC, Richards CL (1998) Effects of wrack burial in salt-stressed habitats: Batis maritima in a Southwest Atlantic salt marsh. Ecography 21:630-638

Sarneel JM, Janssen RH, Rip WJ, Bender IMA, Bakker ES (2014) Windows of opportunity for germination of riparian species after restoring water level fluctuations: a field experiment with controlled seed banks. J Appl Ecol 51:1006-1014

Sayer EJ (2006) Using experimental manipulation to assess the roles of leaf litter in the functioning of forest ecosystems. Biol Rev 81:1-31

Shumway SW, Bertness MD (1992) Salt stress limitation of seedling recruitment in a salt-marsh Plant community. Oecologia 92:490497

Török P, Helm A (2017) Ecological theory provides strong support for habitat restoration. Biol Conserv 206:85-91

Török P, Bullock JM, Jiménez-Alfaro B, Sonkoly J (2020) The importance of dispersal and species establishment in vegetation dynamics and resilience. J Veg Sci 00:1-8

Vaccaro LE, Bedford BL, Johnston CA (2009) Litter accumulation promotes dominance of invasive species of cattails (Typha Spp.) in Lake Ontario wetlands. Wetlands 29:1036-1048
Xiong SJ, Johansson ME, Hughes FMR, Hayes A, Richards KS, Nilsson C (2003) Interactive effects of soil moisture, vegetation canopy, plant litter and seed addition on plant diversity in a wetland community. J Ecol 91(6):976-986

Zamin TJ, Jolly A, Sinclair S, Morgan JW, Moore JL (2018) Enhancing plant diversity in a novel grassland using seed addition. J Appl Ecol 55:215-224

Zeiter M, Stampfli A (2008) Long-term assessment of seed provenance effect on the establishment of the perennial grass Bromus erectus. $\mathrm{J}$ Veg Sci 19:821-U813

Zhang LW, Wang BC (2016) Intraspecific interactions shift from competitive to facilitative across a low to high disturbance gradient in a salt marsh. Plant Ecol 217:959-967

Zhang LW, Wang BC (2019) The influence of nutrient addition on the invasion of Spartina alterniflora towards the non-tidal wetlands in the Chinese Yellow River delta. J Coast Conserv 23:623-631

Zhang LW, Wang BC, Qi LB (2017) Phylogenetic relatedness, ecological strategy, and stress determine interspecific interactions within a salt marsh community. Aquat Sci 79:587-595

Publisher's note Springer Nature remains neutral with regard to jurisdictional claims in published maps and institutional affiliations. 